\title{
Imperfect Victory: The Legal Struggle for Blackbird Bend, 1966-1995
}

\author{
MARK R. SCHERER
}

THE "RED POWER" MOVEMENT of the 1960s and early 1970s played a pivotal role in modern Indian affairs. During that era, Native American groups operating under the rather loose banner of the American Indian Movement (AIM) became embroiled in a series of confrontations with federal authorities, some of which involved violent "self-help" tactics. Among the most notable episodes were the Indian occupation of Alcatraz Island in San Francisco Bay from November 1969 to June 1971; the "Trail of Broken Treaties," culminating in the occupation and destruction of the Bureau of Indian Affairs headquarters building in Washington, DC, in November 1972; the AIM occupation of the tiny village of Wounded Knee on the Pine Ridge Reservation in South Dakota, and the ensuing federal siege from February 27 to May 8, 1973; and, perhaps most tragically, the June 1975 shoot-out between AIM and the FBI at Pine Ridge that left an Indian and two federal agents dead. ${ }^{1}$

I am greatly indebted to Michael Tate for his guidance in the fashioning of this article. Many thanks also to Marvin Bergman, John Wunder, and an anonymous reader for the Annals of Iowa for their valuable suggestions, and to Marvin Barton for his mapmaking expertise. Finally, I wish to thank the Omaha tribal members and non-Indian residents of Thurston County who cooperated in my telling of this story.

1. The literature on the "Red Power" movement of the late 1960s and early 1970 s is abundant. Among the more detailed examinations of these events (generally told from the Indian point of view) are Paul Chaat Smith and Robert Allen Warrior, Like a Hurricane: The Indian Movement from Alcatraz to Wounded Knee (New York, 1996); Peter Blue Cloud, ed., Alcatraz Is Not an

THE ANNALS OF IOWA 57 (Winter 1998). ๑The State Historical Society of Iowa, 1998. 
While all of those events generated widespread national publicity, the "Red Power" movement came to western Iowa much more quietly, in the form of a remarkably complex legal struggle waged by the Omaha Tribe of Nebraska. Beginning in 1966, the Omahas sought to regain possession of more than eleven thousand acres of land situated east of the Missouri River. The tribe claimed that the land had been a part of its reservation in Nebraska before changes in the river channel moved it to the Iowa side. The ensuing legal struggle in the state and federal courts, which became known as the "Blackbird Bend litigation," spanned almost two decades, ultimately producing a profound economic and emotional impact on both the tribe itself and the citizens of western Iowa. As the litigation wove its tortuous path through the court systems, the atmosphere in and around Monona County became so emotionally charged that one contemporary observer warned that the river might "run red" with the blood of the participants.

Fortunately, that ominous prediction proved incorrect; no blood was shed at Blackbird Bend. Nonetheless, the litigation generated animosity, frustration, and resentment that lingers in some quarters of the region to this day, not only among the Omahas and their non-Indian opponents, but also between the tribe and its designated federal "representatives," and even on occasion among tribal members themselves.

Arising as it did in an era of particularly volatile Indiangovernment relations, when Native Americans were asserting their rights through increasingly strident and sometimes "extra-legal" means, the Omahas' struggle to reclaim Blackbird Bend stands as a compelling case study in nonviolent Indian judicial activism. As historian John Wunder has noted, the federal courts' treatment of Indian legal claims is a "story of continuity and change ... that must be constantly told and retold. ${ }^{2}$ The Blackbird Bend saga offers a noteworthy chapter in that continuing story.

Island (Berkeley, CA, 1972); Robert Burnette and John Koster, The Road to Wounded Knee (New York, 1974); Vine Deloria Jr., Behind the Trail of Broken Treaties: An Indian Declaration of Independence (New York, 1974); and Peter Matthiessen, In The Spirit of Crazy Horse (1983; reprint, New York, 1991).

2. John R. Wunder, "Retained by the People": A History of American Indians and the Bill of Rights (New York, 1994), 213. 
The final outcome of the Blackbird Bend litigation cannot be captured in simple terms of a legal victory or defeat for either the Omahas or the white Iowans who opposed them. At first glance, the twelve published decisions rendered by the courts seem to indicate that the Omahas succeeded in regaining their land. The tribe was, however, bitterly disappointed with the final outcome of the litigation. Theirs was, at best, an imperfect victory, for the Omahas ultimately obtained title to only a small portion of the total acreage they claimed, and they felt that they were the victims of fraud and breach of trust by the federal judiciary and the Department of Justice throughout the proceedings. Yet the Omahas' opponents could not be wholly satisfied with the legal outcome either. For the white farmers in Iowa who had asserted title to the land prior to the litigation, the loss of even a single acre was a bitter pill to swallow. Even those Iowans whose title to the property was ultimately upheld by the courts incurred substantial legal expense and endured years of uncertainty as the cases plodded through the system.

The Blackbird Bend litigation received substantial contemporaneous attention in regional newspapers and the popular press. ${ }^{3}$ Academic commentary on the matter, however, is relatively scarce, and has generally focused on specific aspects of the parties' claims or the courts' holdings in isolated portions of the litigation. Notwithstanding those admirable examinations of certain parts of the story, the entire Blackbird Bend dispute has yet to be fully synthesized, and it remains a subject of national import on several levels.

Viewed from the most technical perspective, the Blackbird Bend decisions produced significant judicial statements on the rather arcane subject of riparian landowners' rights, as those rights are affected by the complex geological actions known as

3. The Omaha World-Herald, Sioux City Journal, Lincoln Star, and Des Moines Register all provided extensive coverage of the litigation. In addition, the early stages of the Blackbird Bend litigation are the subject of a recent delightfully written essay titled "Blackbird's Ghost," in Theodore Steinberg, Slide Mountain: Or, The Folly of Owning Nature (Berkeley, CA, 1995), 21-51. See also Ros Jensen, "Blackbird Bend: Landmark Victory in Land Dispute," Christian Century 95 (714 June 1978), 606-8. 
"accretion" and "avulsion." ${ }^{4}$ In addition, the dispute required the courts to interpret and apply a federal statute enacted in 1834 that gave a clear judicial preference to Indian claimants in any boundary litigation with "white persons." ${ }^{5}$ That statute had never previously been invoked or interpreted by the courts, and its constitutionality and applicability to the Blackbird Bend dispute became the subject of substantial debate, both among the parties and in the academic press.

On another level, the Blackbird Bend litigation provides valuable insight into the often overlooked "human" dimensions of legal issues relating to land ownership. Both the Omahas and the Iowans pursued their claims with a dogged determination that occasionally approached violence, offering stark evidence of the deep emotional bonds that tie persons to the lands of their ancestors. That emotionalism grew stronger as the litigation made its way through the court system, eventually overshadowing the rather staid legal concepts at issue in the cases. Indeed, the lingering discontent and resentment on both sides of the litigation is one of the most troubling "legacies" of the Blackbird Bend saga.

Perhaps most significantly, Blackbird Bend offers an important opportunity to examine the localized impact of federal Indian policy, specifically in the context of the federal government's paternalistic and often troublesome role as the contin-

4. For academic analysis of this aspect of the Blackbird Bend story, see Laurie Smith Camp, "Land Accretion and Avulsion: The Battle of Blackbird Bend," Nebraska Law Review 56 (1977), 814-35; and Daniel Henry Ehrlich, "Problems Arising from Shifts of the Missouri River on the Eastern Border of Nebraska," Nebraska History 54 (1973), 341-63.

5. 25 U.S.C. section 194 (1834).

6. See Margaret Hotopp, Comment, "Preferential Burden of Proof Allocation in Indian Land Claims Cases," Iowa Law Review 64 (1979), 386-407. See also Mark W. Thomas, "Constitutional Law-Equal Protection-Supreme Court Upholds Validity of Preferential Treatment of Indians in Land DisputesWilson v. Omaha Indian Tribe," Creighton Law Review 13 (1979), 619-32, wherein the author suggests that the statute's effect is "academically suspect but morally persuasive." See also Rjean K. Formanek, "Blackbird Hills Indian Land Dispute Settled by Placing the Burden of Proving Title on the NonIndian Party and Incorporating Nebraska Water Law into the Federal Standard," Creighton Law Review 13 (1980), 1098-1102. 
uing "trustee" of Indian lands. ${ }^{7}$ The court documents, transcripts, and other records pertaining to the litigation reveal an extremely antagonistic relationship between the Omahas and the government attorneys who were bound by law to act on the tribe's behalf. Throughout the proceedings, the Omahas found themselves "represented" by officials who did not share their view of the facts or the law, and whose "assistance" the tribe would have much preferred to do without. ${ }^{8}$ The Omahas' conflict with their purported "trustee" is the more obscure "story within the story" at Blackbird Bend-an extremely significant part of the picture that is not readily apparent in the published case law, the contemporary news accounts, or the academic analysis of the litigation. For the Omahas, however, those conflicts were every bit as much a part of the Blackbird Bend story as the court decisions themselves.

ACTUAL LITIGATION in the Blackbird Bend case would not commence until 1975, but the Omahas began giving formal notice of their claims to the Blackbird Bend area as early as 1966. In February of that year, Tribal Chairman Alfred Gilpin first indicated that the Omahas had "staked their claim" to the Iowa land with officials of the Bureau of Indian Affairs (BIA), and that "action was pending" on the matter.' The

7. Scholarly discussion of the recurring problems inherent in the government's ambiguous role as "trustee" of Indian lands is abundant, and provides a useful secondary context for this article. See, for example, Robert T. Coulter and Steven M. Tullberg, "Indian Land Rights," in The Aggressions of Civilization: Federal Indian Policy since the 1880s, ed. Sandra L. Cadwalader and Vine Deloria Jr. (Philadelphia, 1984), 198-203, describing the trust relationship as "racial discrimination and boundless United States power disguised as moral and legal duty." In The Great Father: The United States Government and the American Indians, 2 vols. (Lincoln, NE, 1984), 2:1202-6, Francis Paul Prucha laments the "murkiness" that pervades the trust relationship, clouding the already ambiguous line between Indian self-determination and federal paternalism. For a cogent synthesis of the legal bases for the trust relationship, see William C. Canby Jr., American Indian Law in a Nutshell (St. Paul, MN, 1988), 37-52.

8. The government's duty to "represent" the Omahas at Blackbird Bend emanates from the "murky" trust relationship referred to previously. Where, as here, the "trustee" takes an entirely different view of the issue at hand than does the "beneficiary," the potential for bitter conflict is apparent.

9. Omaha World-Herald, 11 February 1966. 
tribe's stated objective was to gain "official recognition" of the land as a part of the Omaha Reservation. That initial claim encompassed three full sections and parts of three others, as the area was then platted by the state of Iowa.

From the beginning of the dispute, the Omahas' claims were grounded in the language of their landmark 1854 treaty with the federal government, in which they ceded the remainder of their traditional hunting grounds on both sides of the Missouri River in exchange for a three-hundred-thousand-acre reservation in northeastern Nebraska. ${ }^{10}$ The precise acreage set aside for the Omaha Reservation was not formally established until 1867, when T. H. Barrett surveyed the boundaries for the General Land Office. The Barrett Survey established the eastern boundary of the reservation as the "centre" of the Missouri River's main channel. ${ }^{11}$ At the time of the survey, the reservation acreage included a thumb-like "meander lobe" known as "Blackbird Bend," jutting east from Nebraska toward Iowa (see map 1). Over the next seventy years, until the Corps of Engineers stabilized the river channel in the 1940s, the river meandered back and forth over the Blackbird Bend lands. Ultimately the river "straightened" itself to the west and south, leaving the Blackbird Bend lobe on the Iowa side of the river. As that land was cut off from the remainder of the reservation, non-Indians in Iowa gradually took control of the property. ${ }^{12}$

10. The full text of the 1854 Treaty may be found in U.S., Statutes at Large 10 (16 March 1854), 1043, and in Charles J. Kappler, ed., Indian Affairs: Laws and Treaties, 2 vols. (Washington, DC, 1904), 2:611.

11. United States v. Wilson, 433 F. Supp. 67 (W.D. Iowa 1977), Finding of Fact 4, p. 68.

12. The precise manner in which the Iowa farmers gained possession of the land is itself a rather elusive story. It appears that by the early 1920 s, a man named Joe Kirk had taken control of most of the property, building a log cabin and cultivating clover and alfalfa on various portions. Kirk sold off the land in 1948, and it changed hands several times thereafter until 1959, when Charles Lakin and Raymond G. Peterson took title to separate portions of the tract. In 1972, Lakin gave about 1,000 acres to the state of Iowa for recreational development, and sold 2,100 acres to Roy Tibbals Wilson, who was renting the land to tenant farmers at the time the litigation commenced. Further complicating the question of title was the fact that the land was not taxed in Iowa until 1969, after Lakin had commenced several "quiet title" actions against adjoining white landowners. See Charles E. Lakin v. State of Iowa, et. al., Equity No. 17400, Monona County District Court, decree filed November 15, 1963. The Omahas 


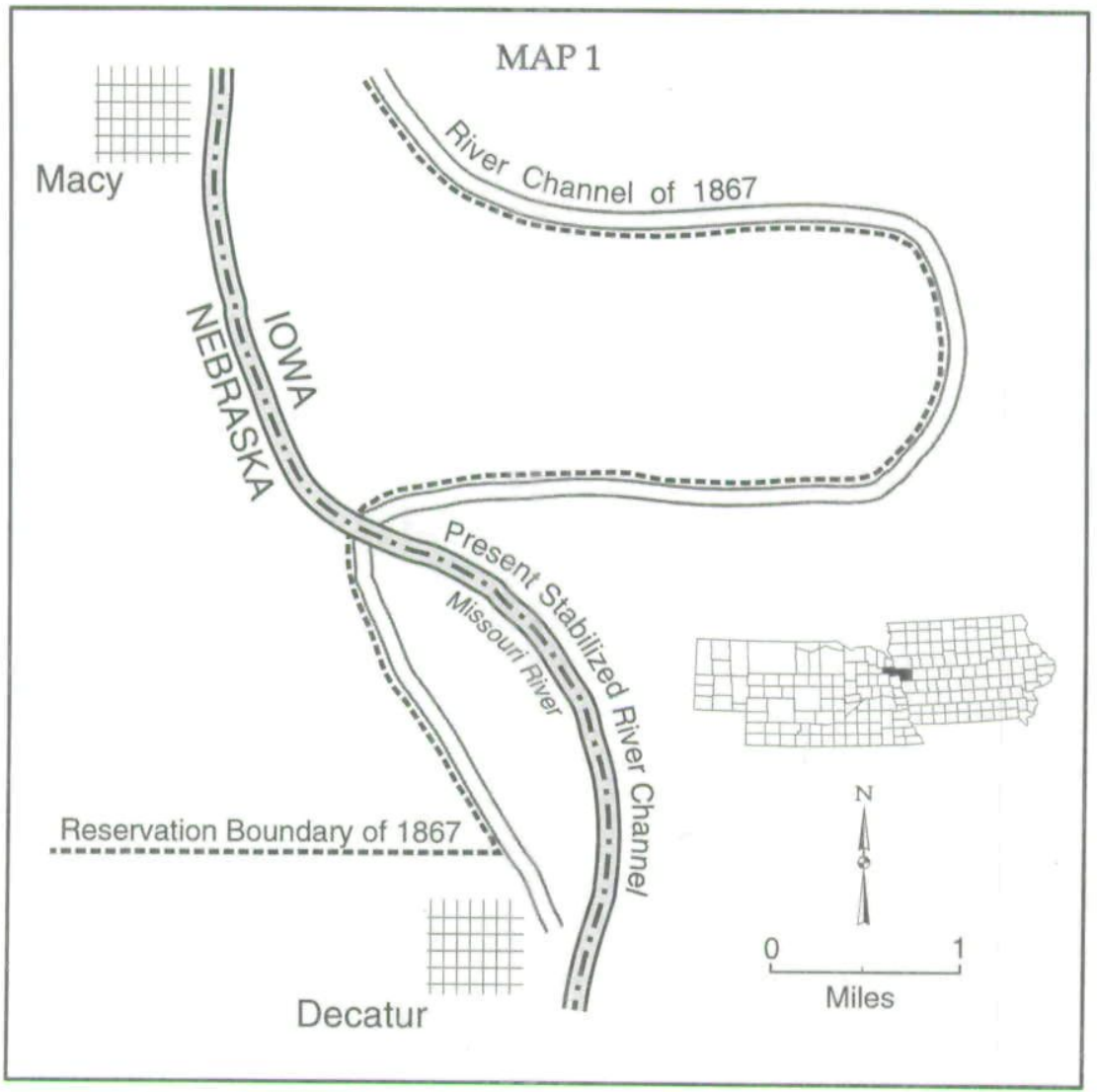

In asserting its claim to those Iowa lands, the Omaha tribe swept itself and its opponents into a judicial maelstrom-one that would weave an incredibly complex trail through the federal court system over a period of almost twenty years. In addition to the U.S. Supreme Court's review of the dispute, the Eighth Circuit Court of Appeals would address the case on seven separate occasions, and the Federal District Court for

were not named as parties in those lawsuits, and would later argue, with justification, that those judgments were not controlling on the question of the tribe's original title. See Sioux City Journal, 6 April 1973; Omaha World-Herald, 6 and 7 April 1973. See also Steinberg, Slide Mountain, 29-31; and United States v. Wilson, 433 F. Supp. 67 (W.D. Iowa 1977), at 83-84. 
the Northern District of Iowa would render four separate published opinions in the cases. ${ }^{1}$

The Omahas' "notice" to the BIA in early 1966 produced no immediate results. In December of that year, the tribe announced that the matter was "in the hands of their attorneys" for the possible filing of a lawsuit to reclaim the land. Despite that hint of immediate action, the issue lingered for several more years while the tribe conferred with BIA officials and Interior Department attorneys regarding the details of their claim. ${ }^{14}$

In August 1972 Nebraska Senators Roman Hruska and Carl Curtis, joined by Representative Charles Thone, delivered a letter to Indian Commissioner Louis Bruce, asking the BIA to allocate fifty thousand dollars to help settle the simmering

13. The sequence of events in the federal courts will be discussed more fully in the remainder of this article. The chronology of the reported decisions is as follows: United States v. Wilson, 433 F. Supp. 57 (W.D. Iowa 1977); United States v. Wilson, 433 F. Supp. 67 (W.D. Iowa 1977); Omaha Indian Tribe v. Wilson, 575 F.2d 620 (8th Cir. 1978); Wilson v. Omaha Tribe, 442 U.S. 653 (1979); Omaha Indian Tribe v. Wilson, 614 F.2d 1153 (8th Cir.), cert. denied 449 U.S. 825 (1980); United States v. Wilson, 523 F. Supp. 874 (W.D. Iowa 1981); United States v. Wilson, 707 F.2d 304 (8th Cir. 1982), cert. denied 465 U.S. 1025 (1984); United States v. Wilson, 578 F. Supp. 1191 (W.D. Iowa 1984); Omaha Indian Tribe v. Jackson, 854 F.2d 1089 (8th Cir. 1988), cert. denied 490 U.S. 1090; United States v. Wilson, 926 F.2d 725 (8th Cir. 1991); Omaha Indian Tribe v. Tract 1-Blackbird Bend Area, 933 F.2d 1462 (8th Cir.) (per curiam), cert. denied sub nom. Omaha Indian Tribe v. Agricultural \& Indus. Inv. Co., 502 U.S. 942 (1991); Rupp v. Omaha Tribe, 45 F.3d 1241 (8th Cir. 1995).

14. Omaha World-Herald, 23 December 1966. From 1966 to 1972, tribal attention was diverted by several other lawsuits relating to the ownership of riparian land on the reservation. In one of those cases, Victor Fontanelle, grand-nephew of famed Omaha Chief Logan Fontanelle, sought title to some three hundred acres of land along the river that he claimed had "accreted" to his family's allotment on the reservation. Following a trial of the matter in April 1967, the Federal District Court for Nebraska ruled in Fontanelle's favor in 1969. See Fontanelle v. Omaha Tribe of Nebraska, 298 F. Supp. 855 (D. Neb. 1969). The decision was affirmed on appeal to the Eighth Circuit Court of Appeals. Omaha Tribe of Indians v. Fontanelle, 430 F.2d 143 (8th Cir. 1970). See also Omaha WorldHerald, 12 and 13 April 1967. In a separate matter occurring at about the same time, several Iowa farmers asserted title to land on the western side of the river within the reservation, which they claimed had shifted to the Nebraska side by the river's movement. The Omahas did not contest the Iowans' title to the land. The dispute centered on the farmers' attempts to bulldoze a road through the reservation to gain access to the site. See Omaha World-Herald, 23 March 1968. 
boundary dispute along the river. Bruce was advised that the Omaha and Winnebago Tribes claimed as much as nine thousand acres on the Iowa side of the river, which was "being used for private gain by Iowa farmers and the state government." ${ }^{15}$ Before the BIA's bureaucratic machinery plodded into action, however, the burgeoning spirit of Indian political activism that swept the United States in the early 1970s found its way to the Omaha Reservation, bringing the Blackbird Bend dispute to a potentially dangerous head.

ON APRIL 3, 1973, twelve carloads of Omaha Indians moved onto a portion of the Blackbird Bend lands in Monona County. Led by former (and future) tribal chairman Edward Cline, the "occupying force" pitched several tipis and tents on the land, announcing their intention to remain indefinitely, and to farm the ground for tribal benefit. ${ }^{16}$ They also brought with them, and displayed prominently for the local press who converged on the site, a large framed copy of the 1854 treaty on which their claim was based. Most of the participants identified themselves as members of the American Indian Movement (AIM), an organization that had achieved nationwide notoriety in the preceding years as an aggressive advocate of Indian rights. Indeed, the occupation of Blackbird Bend occurred almost simultaneously with the resolution of one of AIM's most renowned actions - the Indian occupation and subsequent government siege of the village of Wounded Knee on the Sioux's Pine Ridge Reservation in South Dakota. ${ }^{17}$

With the violence at Wounded Knee fresh in everyone's mind, the Omahas and local officials all expressed hope that

\section{Omaha World-Herald, 31 August 1972.}

16. Sioux City Journal, 6 April 1973; Omaha World-Herald, 6 April 1973.

17. The juxtaposition of the Omahas' occupation of Blackbird Bend and the resolution of the AIM occupation of Wounded Knee is starkly reflected on the front page of the April 6, 1973, Sioux City Journal. The lead story at the top of the page provides the paper's first report of the Omahas' action at Blackbird Bend, while an Associated Press story at the bottom of the same page is headlined "Peace Comes to Wounded Knee." For more on AIM and Wounded Knee, see Burnette and Koster, Road to Wounded Knee; Deloria, Behind the Trail of Broken Treaties; and Matthiessen, In the Spirit of Crazy Horse. 


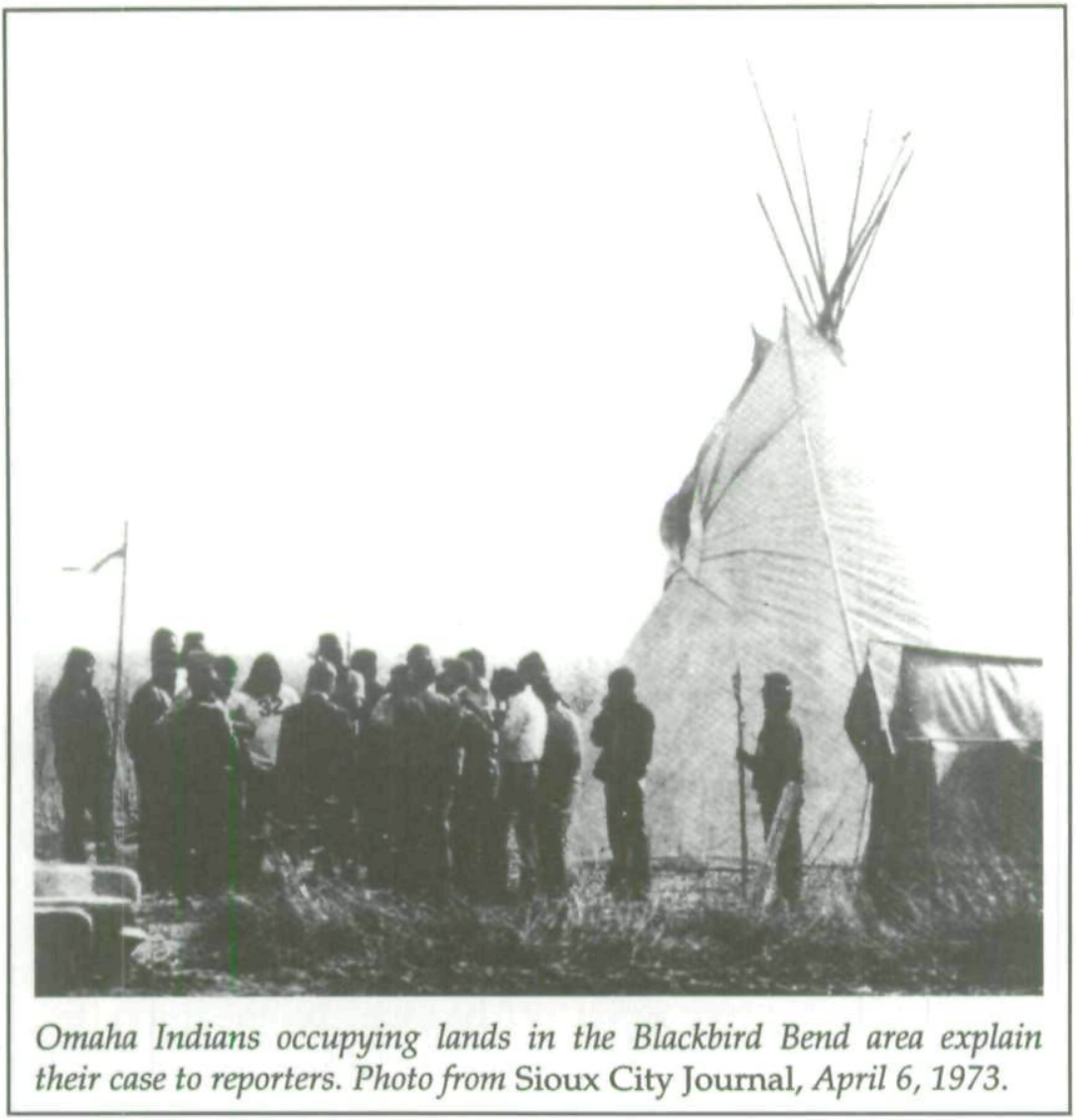

Blackbird Bend "would not turn into another Wounded Knee." ${ }^{18}$ Tensions ran high nevertheless, as Cline informed authorities that the Omahas, although unarmed, would resist efforts to remove them from the land. Two days after the occupation began, the Indians met at the site with a group of attorneys representing the Iowa claimants of the land. The thirty-minute conference brought no appreciable change in the parties' positions. The attorneys maintained that their clients had obtained title to the land through several "quiet title" actions prosecuted in the Iowa state courts in previous years. ${ }^{19}$ The Omahas

18. Omaha World-Herald, 6 April 1973.

19. A "quiet title" action is one in which a court is asked to resolve competing claims to disputed real property. Theoretically, all parties who claim an interest 
argued that those decisions had no effect on their ownership of the land since the tribe had not been named as an interested party in the suit, and the Iowa courts had no jurisdiction over an Indian reservation. The occupiers also told reporters that they would "defend our land the way you would defend your home," and blamed the federal government for failing to protect the tribe's interests as the land had slipped into white control. $^{20}$

Several weeks later, the Monona County Sheriff's Department arrested Cline and two white farmers on larceny charges after the men picked corn that Iowans had planted on the disputed land. The two white men were released routinely on bond, but Cline chose to remain in jail. He was released five days later after a preliminary hearing. The charges against the men were referred to the Monona County grand jury to determine whether indictments were warranted.

While those criminal proceedings were pending, one of the Iowa lessees of the land, Harold Jackson, initiated a civil action against Cline and the other occupying Indians to try to regain possession. Monona County District Court Judge Donald Pendleton heard the matter on May 7. Nine days later, Pendleton issued an order requiring Cline and the other Omahas to vacate the land, pending further hearings on the question of title to the property. This opening round in the struggle for Blackbird Bend then quickly subsided as Cline and the other Indians left the property before Monona County Sheriff Albert Wood arrived to formally serve them with Pendleton's order. ${ }^{22}$

The Omahas were not sufficiently funded or unified to sustain their initial occupation of Blackbird Bend in 1973. Because the Omaha tribal council had not endorsed the AIMsponsored action, Cline and the other AIM members were

in the disputed property are notified of the action and given the opportunity to assert and prove their claims.

20. Omaha World-Herald, 7 and 10 April 1973.

21. Ibid., 22, 23, and 26 April 1973. The headline the second day indicated that the two other men arrested along with Cline were also Indians; actually, however, they were white farmers Harold Swanson Jr. and Kenneth Davis, who had been hired to assist the Omahas with their farming operation on the land.

22. Ibid., 7, 9, and 19 May 1973. 
forced to look elsewhere for financial assistance. ${ }^{23}$ When that effort failed, the occupiers retreated, but they remained committed to the goal of gaining the disputed lands.

Meanwhile, the BIA, which had been asked to address the matter more than seven years earlier, finally lurched into limited action. Wyman Babby, Aberdeen Area Director for the BIA, requested a formal opinion on the question of title from the Solicitor of the Department of Interior. ${ }^{24}$ When that opinion was issued in February 1975, and the leadership of the tribal council changed in the interim, the stage was set for the Omahas to return to Blackbird Bend.

ON APRIL 2, 1975, members of the tribe reoccupied the Blackbird Bend lands. Several key elements distinguished this effort from the short-lived 1973 sit-in. First and most significantly, the Omaha tribal council, which was now chaired by the leader of the failed 1973 action, Edward Cline, fully endorsed the 1975 occupation. Whatever AIM presence may have remained from 1973 was no longer visible in 1975, and the tribe presented a unified front in asserting its right to the land. ${ }^{25}$ The occupiers constructed a small heated cottage on the property and erected signs reading "Boundary line Omaha Indian Reservation. No trespassing. Federal law prohibits damage or removal of this sign. Violators will be prosecuted. Omaha Tribal Council." They were prepared for a long stay (see cover). ${ }^{26}$

BIA officials, buttressed by an Interior Department opinion in which the federal government formally asserted Indian title to the property, also supported the 1975 occupation. That opin-

23. lbid., 1 May 1973.

24. Ibid., 9 May 1973.

25. See Omaha Tribal Resolutions Nos. 75-28 and 75-31, and "Affidavit of The Omaha Indian Tribal Council," announcing the council's unanimous endorsement of the occupation, and further indicating that the action had been taken "with the full approval, knowledge, and direction of the Acting Commissioner of the Bureau of Indian Affairs, Jose A. Zuni." All three of these documents are attached as exhibits to the Omahas' "Complaint for Injunction," filed 20 May 1975, Case No. C75-4026, Federal District Court for Northern District of Iowa, Western Division.

26. Omaha World-Herald, 8 April 1975. 
ion, authored by Interior Department Solicitor Kent Frizzell, declared that the disputed lands had been a part of the Omaha Indian Reservation since 1854, and that title should be vested in the United States as trustee for the tribe. Based on that conclusion, BIA attorney Herbert Becker publicly reiterated the Omahas' original argument that the earlier "quiet title" actions in the Iowa state courts had not resolved the question of title to the property, since neither the Omahas nor the federal government had been named as parties in that suit. ${ }^{27}$ Beyond Frizzell's assertion of Indian title to the property, however, there was little agreement between the Omahas and the federal government on any other issue relating to the Blackbird Bend dispute. Indeed, from that point on, the tribe would find itself spending nearly as much time battling its purported governmental "representatives" as it would in fighting the Iowa claimants of the land.

The BIA's initial proposal for resolving the Blackbird Bend dispute suggested that the Iowans continue to farm the land under a lease arrangement with the federal government as trustee for the tribe. Not surprisingly, that proposal held little appeal for either the Omahas or the Iowa farmers. The Omahas did not want to lease to the Iowa claimants, since the tribe's constitution gave tribal members first priority in the awarding of leases. ${ }^{28}$ For their part, the Iowans expressed little interest in renting land that they believed they had owned for decades. ${ }^{29}$

27. Memorandum from Solicitor Kent Frizzell to Commissioner of Indian Affairs, 3 February 1975. Although the memo is not published in the reported opinions of the Interior Department, it is attached in its entirety to the Omahas' "Complaint for Injunction," filed 20 May 1975, Case No. C75-4026, Federal District Court for Northern District of Iowa, Western Division. See also Omaha World-Herald, 8 April 1975.

28. See "Constitution and By-Laws of the Omaha Tribe of Nebraska," Article VIII, section 5, reprinted in George E. Fay, comp., Charters, Constitutions, and By-Laws of the Indian Tribes of North America: Part 13, Midwestern Tribes, Occasional Publications in Anthropology, Ethnology Series, No. 14 (Greeley, CO, 1972), 53.

29. The Iowans' perspective on this and other issues in the early stages of the Blackbird Bend litigation is reflected in an untranscribed interview with an attorney representing one of the Iowa claimants. See Richard W. Peterson, interview with Peter J. Peters, 26 January 1976, American Indian Oral History Project, Department of History, University of Nebraska at Omaha. 
Even if the Omahas had been amenable to the BIA's leasing proposal, significant disagreements remained over the specific manner in which Omaha title to the property would be formally established. Because the Iowa claimants were not likely to agree to being ousted without first having their day in court, BIA attorneys advised the Omahas that court action would be required to fully establish the tribe's ownership. Having waited almost ten years for the government to take action on their claims, however, the Omahas were in no mood to wait for the courts to grind their way to a decision in the case.

In a meeting with BIA Commissioner Morris Thompson and Interior Department attorneys shortly after the 1975 occupation began, Edward Cline and other tribal officials resisted the attorneys' efforts to convince them to vacate the land while the government prosecuted a lawsuit on the tribe's behalf. Cline asked, "Why can't we go ahead and make like we own it? We're not going to hassle these people. But we are prepared to defend ourselves." Acknowledging that the BIA should have resolved the matter years earlier, but also believing that violence and bloodshed were imminent, Interior Department Solicitor Kent Frizzell begged the Omahas to leave the property and give him a chance to fight their battle in court "with clean hands." Cline reluctantly agreed to discuss Frizzell's recommendations with the full tribal membership, but the Omahas did not move off the property, and even bigger disagreements with the government attorneys loomed.

ON MAY 19, 1975, the U.S. Department of Justice, acting as trustee for the Omaha Tribe, filed suit in the U.S. District Court for the Northern District of Iowa. The suit sought to establish that approximately 2,900 acres within the original Barrett Survey of the Blackbird Bend meander lobe belonged to the Omaha Tribe. In its complaint, the government also asked for immedi-

30. Omaha World-Herald, 28 May 1975.

31. Ibid., 9 April 1975. 
ate injunctive relief allowing the tribe to maintain control of the land it had occupied since April 2 . $^{32}$

Far from being appeased by this long-awaited "action" taken by their purported "trustee," the Omahas were outraged by the allegations in the government's complaint. The tribe viewed the government's claim as precipitous and unduly "constricted" because it asserted Omaha title to only a small fraction of the total acreage that the tribe felt it owned. More grievously, the Omahas believed that the Department of Justice attorneys were acting in concert with Iowa state officials and the "politically and financially powerful squatters occupying the Tribe's lands" to defraud the tribe.

Kent Frizzell defended the government's action as a legitimate attempt to forestall violence and bloodshed at Blackbird Bend. ${ }^{34}$ In a letter to Cline, Frizzell wrote,

I can appreciate the tribe's justifiable frustration after 40 years of trying to secure department support for its title claim. I cannot be responsible for, nor can I justify, past inaction. By the same token, I cannot rectify the consequences of that action overnight. Courts exist so as to settle controversies in an orderly fashion. The alternative to such settlement is too often bloodshed.

On the day after the government filed its "quiet title" action, the tribe filed a complaint of its own, prepared by private counsel John T. O'Brien of Sioux City, asking that the Iowa claimants be restrained from interfering with the tribe's possession of the land. ${ }^{36}$ That suit did not seek "quiet title" to any

32. "Complaint to Quiet Title and for Injunctive Relief," 19 May 1975, Case No. C75-4024, Federal District Court for Northern District of Iowa, Western Division.

33. Over the ensuing twenty years of court action, the tribe persistently argued that the Department of Justice had fraudulently failed to meet its trust obligations to the tribe. The Omahas repeated those allegations in countless resolutions, pleadings, motions, and briefs filed with the courts during the long history of the case. One of the earliest formal assertions of those feelings is found in Omaha Tribal Resolution No. 75-40, dated 28 May 1975, in which the tribal council accused the government attorneys of "gross double dealings, manipulation and abuse."

34. Omaha World-Herald, 3 June 1975.

35. Kent Frizzell to Eddie Cline, quoted in Omaha World-Herald, 3 June 1975.

36. “Complaint for Injunction, for a Stay of State Court Proceedings and Other 
of the disputed land, because the Omahas did not feel that all the preparation had yet been completed to conclusively establish their ownership of all the land at issue. Rather, the tribe sought only to maintain its occupancy of the land and, just as significantly, to serve notice of their strong opposition to the "constricted" complaint purportedly filed on their behalf by the federal government on the previous day. ${ }^{37}$

Two weeks later, the Omahas filed a motion to dismiss the government's complaint, arguing that the tribe's interests were not being adequately represented in that proceeding. In a tribal resolution attached to the motion, the Omahas contended that they had been "grossly and completely abandoned by the Department of Justice," and that the Attorney General and Secretary of the Interior had breached their trust responsibilities by secretly acting in concert with the Iowa claimants.

The Indians argued that the U.S. attorneys who prepared, filed, and prosecuted the complaint had limited the tribe's claim to only 2,900 of the total 6,390 acres within the Blackbird Bend lobe, while completely abandoning the tribe's claim to approximately 5,000 additional acres in two areas north of Blackbird Bend known as the Monona Bend and Omaha Mission Bend tracts. ${ }^{39}$ The Omahas' anger was exacerbated by the fact that the U.S. Attorney who filed the complaint, Evan L. Hultman, had previously served as Attorney General for the state of Iowa. In that capacity, Hultman had represented the state in

Relief," 20 May 1975, Case No. C75-4026, Federal District Court for Northern District of Iowa, Western Division.

37. In their complaint, the Omahas asserted that the government suit initiated on the day before had been "filed over the protests of the Omaha Tribe of Nebraska," and was "in effect a conduit to permit and allow [the Iowans] to retake possession of the lands involved." Ibid., II 7.

38. "Application to Dismiss or Hold in Abeyance," 3 June 1975, and attached Omaha Tribal Resolution 75-40, 28 May 1975, Case No. C75-4024, Federal District Court for Northern District of Iowa, Western Division.

39. One of the most comprehensive summaries of the tribe's arguments on the fraud issue may be found in "Motion of Omaha Indian Tribe to Have Disqualified and to Enjoin Evan L. Hultman, United States Attorney, James J. Clear, and Successors from Further Participation in These Cases, and Memorandum in Support," 7 November 1975, Case Nos. C75-4024, C75-4026, and C75-4067 consolidated, Federal District Court for Northern District of Iowa, Western Division (hereafter cited as consolidated federal district court case). 
the earlier "quiet title" actions among the various Iowa claimants. Those cases had been settled by dividing the Blackbird Bend lobe among the Iowa claimants and the state. As a result, the state of Iowa, formerly represented by the same man who now purported to represent the Omahas, now claimed title to about 700 acres of the land sought by the tribe.

Later events gave the Omahas additional reason to doubt Hultman's devotion to their cause. In the summer of 1976, he served as the lead federal prosecutor in the murder trial of two Indians for killing two FBI agents on the Pine Ridge Reservation the previous summer. After the Cedar Rapids jury acquitted the Indian defendants, some Omahas became convinced that "Since he [Hultman] couldn't get us [Indians] there, he would be sure to get us at Blackbird Bend.." ${ }^{\prime 40}$ Regardless of whether those doubts were justified, at least one BIA official acknowledged the potential impact of Hultman's role in the reservation murders case on the Blackbird Bend litigation. On August 9, 1976, Martin E. Seneca Jr., director of the BIA's Office of Trust Responsibility, expressed misgivings about allowing Hultman's office to handle the Blackbird Bend case on behalf of the Omahas because "the recent acquittals in the Pine Ridge murder trials have intensified local tensions between Indians and nonIndians. ${ }^{\prime 41}$ Seneca's concerns were ignored.

On June 5, 1975, Federal District Judge Edward J. McManus granted the Omahas a preliminary injunction allowing them to continue to occupy the land while the litigation was pending. McManus's order also required, however, that all proceeds from the tribe's farming operations on the land be deposited with the court and held in escrow until title to the property could be determined. ${ }^{42}$

40. Wynema Morris, interview with author, 5 February 1997. Morris was a member of the tribal council during much of the Blackbird Bend litigation.

41. Memorandum from Martin E. Seneca Jr., director of the BIA's Office of Trust Responsibility, to Reed Chambers, associate solicitor for Indian Affairs in the Interior Department, 9 August 1976, appended to "Motion of the Omaha Indian Tribe to... Have the Justice Department Aligned as an Adversary in These Consolidated Cases," filed 23 September 1976, consolidated federal district court case.

42. U.S. District Judge Edward McManus, "Order," 5 June 1975, consolidated federal district court case. 
Several weeks later, Judge McManus denied the Omahas' motion to dismiss the government's complaint, holding that the tribe's arguments regarding U.S. Attorney Hultman's conflict of interest were "without merit at this time..$^{\prime 43}$ The Omahas viewed this as simply another example of the governmental conspiracy against them, inasmuch as McManus had been the lieutenant governor of Iowa at the time of the earlier intrastate litigation regarding the Blackbird Bend lands, and was thus well aware of Hultman's prior connection to the case. Over the ensuing years, the federal courts would repeatedly reject the tribe's continuing allegations of fraud and conspiracy among the government attorneys, often imposing sanctions on the tribe for repeatedly raising what the courts deemed to be "frivolous" claims." Nevertheless, the fraud charges would resonate throughout the extended course of the litigation, creating a disturbing atmosphere of hostility that would ultimately contribute to the dismissal of the tribe's claims for most of the land it sought.

BY OCTOBER 1975, the Omahas had completed the preparation of their claim for all of the Iowa land to which they felt entitled. On October 6, attorney John T. O'Brien filed the tribe's second independent complaint in the Blackbird Bend proceedings. In the new action the Omahas named nearly one hundred separate Iowa landowners as defendants, and asserted title to three separate tracts of land totaling 11,300 acres on the eastern side of the river (see map 2). ${ }^{45}$ Tract One encompassed

43. U.S. District Judge Edward McManus, "Order," 1 July 1975, consolidated federal district court case.

44. Notwithstanding the courts' repeated rejection of the Omahas' arguments regarding Hultman's apparent conflict of interest, it should be noted that there indeed seems to be a prima facie appearance of such a conflict. At least one "disinterested" outside party offered support for the tribe on that issue. In 1987 the National Council of Churches filed an amicus brief in which it argued that the Omahas' claims regarding Hultman's conflict of interest were "neither frivolous nor without merit," and that the Department of Justice had "stymied and stultified the efforts of the Tribe to act in its own behalf." See "Motion for Leave to File, Statement of Interest and Brief Amicus Curiae of the National Council of Churches in Support of the Omaha Indian Tribe's Rule 59 Motion," 8 June 1987, consolidated federal district court case.

45. "Complaint," Case No. C75-4067, 6 October 1975, Federal District Court for Northern District of Iowa, Western Division. 


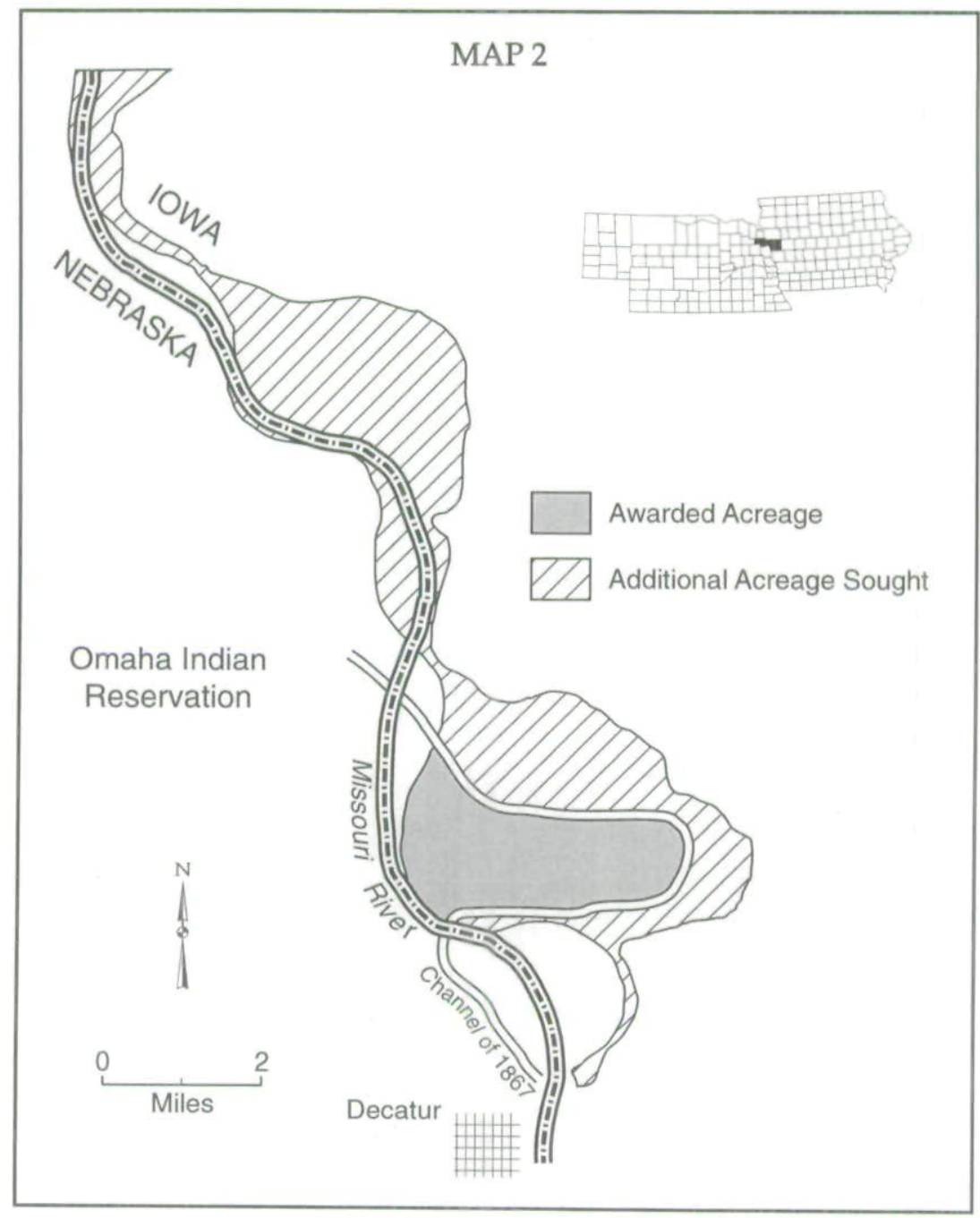

an additional 3,490 acres within the Blackbird Bend meander lobe (in addition to the 2,900 acres within the Barrett Survey claimed for the tribe in the government's suit). Tract Two was the Monona Bend area located north of Blackbird Bend, comprising 4,185 acres. Tract Three was a 725-acre parcel farther to the north known as Omaha Mission Bend. In addition, the tribe's complaint asked for damages in the amount of \$50 million for the defendants' wrongful use of the land over the 
previous fifty years, in contrast to the government's complaint for the Omahas, which sought no monetary relief.

As the dozens of Iowans named in the Omahas' complaint were served with court notices in the case, tensions in the region rose again. Some of the defendants joined forces to fight the lawsuit, creating an organization called the Monona County Landowner's Association. They hired former Iowa Congressman Wiley Mayne as their attorney. All of the named defendants expressed a common resolve to fight for the land they had farmed for decades. Mrs. Howard Miller voiced a common sentiment. "My dad bought this land from the man who homesteaded it. He bought that land, we have title to it and we're not giving it up." Mayne counseled his clients to refrain from resorting to "self-help" measures in defense of their land, despite their understandable shock and anger at being told that they were not rightfully entitled to their property.

The Omahas responded to the Iowans with equal indignation, publicly asserting that those who were now complaining about the tribe's claim had known for years that the land belonged to the tribe, and that they had been merely "squatting on the land for the last fifty years." Attorney John O'Brien defended his clients to reporters, stating, "A great number of people who live there [in Monona County] took over the land when the Missouri was a wild river. They ran people off it and claimed it for their own when it was really Indian land. . . You're going to hear they [the Omahas] are no-good, lazy devils. But they're hard working people trying to get ahead like anyone else."

Edward Cline reported that shots had been fired at the Omahas who were occupying the land, but that "authorities had failed to take action." Despite those reported hostilities, Cline expressed sympathy for the Iowans who were going to lose land to the Omahas. He argued, however, that the fault lay not with the Indians, but rather with the Iowans' attorneys,

46, Vincent Willey (first president of the landowner's association), interview with author, 21 February 1997; Omaha World-Herald, 21 October 1975 (quote), 24 October 1975.

47. Omaha World-Herald, 24 October 1975. 
who had failed to warn them of the potential problems with their titles at the time they acquired the land.

On January 26, 1976, Judge McManus granted a motion filed by the Omahas seeking to have the three pending cases consolidated for trial. ${ }^{49}$ In so doing, he placed in issue the title to all of the Iowa land claimed by the Omahas, thereby effectively overriding the government's "constricted" complaint filed on the Omahas' behalf. Three months later, however, the judge reversed course. On April 5, 1976, he entered a new order in which he held that the tribe's allegations were "hindering an orderly and efficient administration of justice. ${ }^{\prime{ }^{50}}$ McManus therefore severed the Omahas' claims for the additional acreage outside the Barrett Survey Area in Blackbird Bend and their claims for the lands at Monona Bend and Omaha Mission Bend. The net effect of this crucial April 5 decree was to cause the case to proceed to trial on the "constricted" complaint originally filed by the government, leaving the Omahas' claims for the much larger additional areas "on hold" for more than eight years. ${ }^{51}$ While the severance order may arguably have been grounded in legitimate procedural concerns, to the Omahas it signaled a judicial "sell-out" of their claims, and offered further evidence of a continuing governmental conspiracy.

48. Ibid., 26 October 1975.

49. District Judge Edward McManus, "Order," 26 January 1976, Case No. C754067, Federal District Court for Northern District of Iowa, Western Division.

50. District Judge Edward McManus, "Order," 5 April 1976, consolidated federal district court case. The Omahas thereafter consistently referred to this important severance ruling as a sua sponte order, which is one issued by a court on its own volition, without a formal request from any party in the suit. Technically, the April 5 order probably should not be considered sua sponte, since the court also ruled on several pending motions within its decree. It is true, however, that there was no pending motion for severance from any party before the court at the time.

51. The tribe's claims in Case 4067 were formally stayed by the district court in 1979, pending the outcome of the other cases. Those claims were not reactivated until June 15, 1987. See Omaha Indian Tribe v. Tract I-Blackbird Bend Area, 933 F.2d 1462, 1464 (8th Cir. 1991).

52. In response to later tribal arguments regarding the propriety of Judge McManus's severance order, the Eighth Circuit Court observed that the tribe "did not object to the district court's severance order either by motion for reconsideration, request for interlocutory relief, or in any of the subsequent appeals." See 854 F.2d. 1094, n.5. 
THE CASE PROCEEDED TO TRIAL in Sioux City before Judge Andrew W. Bogue on the issue of title to the 2,900 acres within the Barrett Survey. ${ }^{53}$ From November 1 to December 6, 1976, the parties presented voluminous and complex expert testimony and scores of maps, charts, and other documentary evidence seeking to establish the precise nature of the movements of the Missouri River from 1867 until the 1940s.

From a purely legal perspective, the dispositive issue before the court became relatively straightforward. Under centuriesold principles of riparian property law, land that moves to the opposite side of a river by reason of an avulsion remains the property of the original landowner. Courts have traditionally defined an avulsion as the sudden and clearly perceptible shift of identifiable land from one side of a river to the other. If, on the other hand, a river's current causes land on one side of the river to gradually erode away and slowly "re-emerge" by sedimentary action on the opposite side, the newly created land is considered an "accretion" to the property of the owner on that side of the river. ${ }^{55}$ At Blackbird Bend, therefore, the Omahas generally argued that their land had shifted to the Iowa side by avulsion, while the Iowans claimed that the operative geologic forces had been those of erosion and accretion.

53. Bogue, a federal district judge in South Dakota at the time, presided at the Blackbird Bend trial by special appointment. He had been scheduled to hear the "reservation murders" case in Cedar Rapids that summer, but was switched off that case by the Eighth Circuit. He and McManus effectively traded duties, as McManus took over the murder trial. See Ros Jensen, "Blackbird Bend: Landmark Victory in Land Dispute," Christian Century 95 (7-14 June 1978), 607.

54. The trial record contains 3,216 pages of trial transcript and more than 150 exhibits.

55. The doctrines of avulsion and accretion are discussed in all of the reported court decisions in the Blackbird Bend cases. In addition, see Laurie Smith Camp, "Land Accretion and Avulsion: The Battle of Blackbird Bend," Nebraska Law Review 56 (1977), 814-35, and numerous other sources cited therein.

56. The issue was not always as simple as that statement implies. As to the lands claimed by the tribe outside the Barrett Survey line, the Omahas sought to show that the additional land had accreted to the reservation as the river moved eastward after the survey. Thus the reservation had, at first, been increased in size by accretion. They then argued that the newly created land had later been left on the Iowa side by a sudden avulsion of the river back to the west. 
While the relevant legal doctrines could thus be succinctly stated, the application of those principles to the movements of the Missouri River in the Blackbird Bend area from the 1860s to the 1940 s was not nearly as clear-cut. ${ }^{57}$ The difficulty of the court's task is reflected in dicta offered by the judge within his opinion:

The events which the court is obliged to reconstruct occurred long ago and they were events of nature; so far as we know these events were not observed in their entirety by any person who could today be a witness concerning them. ... it becomes apparent that the movements of the Missouri River have not been so clean and precise that they easily fall into legal categories conveyed by the terms "accretion" and "avulsion.,"

Despite those misgivings, Judge Bogue ultimately ruled in favor of the Iowa landowners. He held that the Omahas had failed to sustain their burden of proving that the Blackbird Bend area had been detached from their reservation and redeposited on the Iowa side of the river, consistent with the theory of avulsion. Accordingly, he awarded title to all of the disputed land within the Barrett Survey to the Iowa defendants, and ordered that the funds generated by the Omahas' farming operations during the previous two years be paid to them as well. ${ }^{59}$

The continuing emotional and moral complexity of the dispute was reflected in a supplemental letter from the court delivered to the parties at the time of the decision. In the letter Judge Bogue took the unusual step of revealing his personal feelings about the equities of the case. He wrote of his "distaste

57. The massive amounts of evidence offered by the parties relating to the movements of the river is best presented in Judge Bogue's painstakingly detailed analysis contained in his published decisions in the case. The district court actually rendered two separate opinions. The first, United States $v$. Wilson, 433 F. Supp. 57 (N.D. Iowa 1977), was a memorandum opinion in which the court resolved choice of law problems, analyzed the concepts of avulsion and accretion, and discussed the allocation of the burden of proof in the case. The second opinion, United States v. Wilson, 433 F. Supp. 67 (N.D. Iowa 1977), contained the court's specific findings of fact and conclusions of law on the merits of the dispute.

58. United States $v$. Wilson, 433 F. Supp 67, at 89.

59. Ibid., at 92. 
for the laws of avulsion and accretion which have brought about this seemingly unfair result," and criticized the original creators of the reservation for failing to define the boundaries "by degrees of longitude and latitude or some other permanent type of description." Bogue went on to declare that Blackbird Bend "should have remained the property of the Tribe for evermore no matter whether it was under water or divided in whole or in part by water, and no matter how it got that way." He concluded by suggesting that "the least that should be done is for the Congress to reimburse the Tribe for its loss. If this Court had the power to order such payment, you can rest assured it would be done. ${ }^{\prime \prime 0}$

Judge Bogue's personal sentiments did little to comfort the Omahas. Incensed by the decision, they vowed to remain on the land despite the court's dissolution of the June 5, 1975, injunction, which had given the tribe temporary possession of the land. When Monona County Sheriff Albert Wood and County Attorney Stephen Allen served the "occupying" Omahas with a court order to vacate the property, Edward Cline told them that the tribe would not comply, inasmuch as its attorneys were in the process of appealing the district court's decision. As county officials began to mobilize to remove the Indians by force, the Eighth Circuit Court of Appeals stepped in, issuing a temporary stay of Judge Bogue's decision. That temporary order was subsequently extended, allowing the tribe to remain in possession of the land indefinitely. ${ }^{61}$

On April 11, 1978, the court of appeals reversed the district court's decision, and ordered that title to the land be vested in the Omaha Tribe and the United States as trustee. ${ }^{62}$ Like Judge

60. Judge Bogue's letter to the parties, dated 2 May 1977, has been incorporated into the official record in the consolidated federal district court case. It is quoted and discussed in Camp, "Accretion and Avulsion," 828-29. The letter was also mentioned in the regional press accounts of the decision. See Omaha World-Herald, 5 May 1977; Des Moines Register, 5 May 1977; and Sioux City Journal, 5 May 1977.

61. Omaha World-Herald, 13 and 14 May 1977; "Temporary Order of Stay," 14 May 1977, and "Order of Stay," 24 May 1977, Eighth Circuit Court of Appeals, Case Nos. 77-1384 and 1387 consolidated.

62. Omaha Indian Tribe v. Wilson, 575 F.2d 620 (8th Cir. 1978). 
Bogue's opinion in the district court, the Eighth Circuit's published decision contains a comprehensive analysis of both the voluminous evidence presented in the trial of the case, and the complex principles of law applicable to those facts. Although the appellate court disagreed with certain portions of Judge Bogue's analysis of the defining characteristics of "avulsion" and "accretion," the more fundamental basis for its reversal of the trial court's decision was less esoteric. Writing for a unanimous three-judge panel, Judge Donald Lay held that the district court had improperly placed the burden of proof on the Omahas. Lay cited a rarely invoked federal statute enacted in 1834, which provides, "In all trials about the right of property in which an Indian may be a party on one side, and a white person on the other, the burden of proof shall rest upon the white person, whenever the Indian shall make out a presumption of title in himself from the fact of previous possession or ownership." ${ }^{\prime 63}$ Judge Lay held that the 1854 Treaty established the Omahas' "previous possession and ownership" of the land within the original Barrett Survey. Thus, under the statute, the tribe was entitled to a presumption of title in its favor, and the burden of proof fell on the Iowans to establish that the land had been entirely eroded away from the reservation and accreted to the opposite side. ${ }^{64}$

After an exhaustive analysis of the massive trial record, this time in the context of the reallocated burden of proof, the circuit court ultimately held that the Iowa claimants had established "only speculative inferences" as to whether the river channel had moved as a result of accretion or avulsion. ${ }^{65}$ Accordingly, the court held that the Iowans had failed to sustain their burden of proof at trial, thus necessitating judgment in favor of the Omahas.

63. 25 U.S.C. section 194 (1834) (emphasis added).

64. The Omahas had argued the controlling effect of this statute in the district court, but Judge Bogue rejected its applicability. He held that invocation of the statute presupposed Indian possession of the land in question, and that prerequisite for the statute's application was therefore "inextricably entwined with the merits" of the case. See 433 F. Supp. 57, at 66.

65. 575 F.2d 620, at 651. 
Just as Judge Bogue had expressed his personal distaste for the result at the trial court level, the appellate court acknowledged the seemingly harsh effect of its decision.

We recognize that to require [the Iowans] to prove the cause of the river's movement occurring some 100 years after the event is indeed an onerous burden. This may seem to be an injustice when one considers that the [Iowans] have possessed and continuously farmed the land without protest for nearly 40 years. However, . . . the clear policy of the federal government mandates that the interests of the Omaha Indian Tribe be given their historical and statutory protection. These important possessory land interests cannot be taken away on proof that is basically speculative and conjectural. ${ }^{66}$

Naturally, the Omahas were gratified by the appeals court's decision, while the Iowans expressed "shock and disappointment." Attorney Thomas Burke, representing one of the losing claimants, called the decision a "travesty" that would have far-ranging adverse consequences in other Indian land claims across the country. The Iowans asked the U.S. Supreme Court to accept the case for review, arguing that the 1834 statute created an unconstitutional judicial preference for Indians based solely on race. In November 1978 the Supreme Court agreed to hear the case.

As the parties filed their briefs and awaited the Court's decision, strong feelings continued to simmer at Blackbird Bend. Harold Sorenson, one of the Iowa farmers who claimed part of the disputed land, expressed concern about the future stability of land titles throughout the region, predicting that "If [the Omahas] win this one, there's nothing to keep them from just keeping on going." The Omahas likewise viewed the fight in

66. Ibid.

67. Omaha World-Herald, 12 April and 28 July 1978; "Petitions for a Writ of Certiorari to the United States Court of Appeals for the Eighth Circuit," U.S. Supreme Court, October Term, 1978. Reflecting the national prominence of the case, the attorneys general of thirty other states filed amicus curiae (friend of the court) briefs in the Supreme Court, urging the Court to accept the case for review. See "Brief for Amici Curiae in Support of the State of Iowa's Petition for a Writ of Certiorari to the United States Court of Appeals for the Eighth Circuit," U.S. Supreme Court, October Term, 1978, No. 78-161. See also Omaha World-Herald, 13 November 1978. 
terms of its impact on the future, but for them the essence of the matter was different. As tribal council member Clifford Wolfe Sr. told a reporter, "We think about our children and grandchildren. From the income [derived from the Blackbird Bend land], maybe they'll feel like we're people. Maybe it'll help their schooling, give them something to fall back on. We want that land back. Anyway we can get it back, we want it back." ${ }^{68}$

On June 20, 1979, the Supreme Court rendered its decision. ${ }^{69}$ Like so many decisions of the High Court, its opinion in the Blackbird Bend case failed to settle the matter outright, but rather returned the case to the lower courts for further consideration. The Supreme Court declared that the Eighth Circuit had been correct in applying the "burden of proof" statute to the individual Iowa claimants, but had erred in applying it to the state of Iowa itself, since a state could not be considered a "white person" under the terms of the statute.

On remand, the circuit court reconsidered its analysis of the issues, but once again decided the case largely in favor of the Omahas. ${ }^{70}$ The court entered a final judgment awarding all but 700 of the 2,900 acres within the Barrett Survey area to the tribe. As to the 700 acres claimed by the state of Iowa, the court returned the case once again to the district court for further consideration, with instructions to place the burden of proof back on the tribe.

Over the next eleven years, the seemingly interminable litigation bounced back and forth between the district court and the Eighth Circuit Court five more times on the issue of title to the 700 acres claimed by the state. ${ }^{71}$ As the courts con-

68. Omaha World-Herald, 19 February 1979.

69. Wilson v. Omaha Indian Tribe, 442 U.S. 653, 99 S. Ct. 2529 (1979).

70. Omaha Indian Tribe v. Wilson, 614 F.2d 1153 (8th Cir.), cert. denied 449 U.S. 825 (1980).

71. See United States v. Wilson, 523 F. Supp. 874 (W.D. Iowa 1981), in which Judge Bogue held in favor of the Omahas on the issue of title to the stateclaimed land; United States v. Wilson, 707 F.2d 304 (8th Cir. 1982), cert. denied 465 U.S. 1025 (1984), in which the Eighth Circuit once again reversed Judge Bogue, remanded the case for further consideration, and ordered the district court to award the Iowa landowners the value of the "improvements" made to the property prior to the Omahas' regaining possession; United States $v$. Wilson, 
tinued to reject the Omahas' claims of conspiracy and fraud, relations between the tribe and the federal district court deteriorated beyond repair. When Judge McManus issued an order in the spring of 1987 awarding the remaining land in dispute to the state, members of the tribe physically barred surveyors from the land. McManus held the entire tribal council in contempt of court, and jailed them overnight. They were released only after a tribal resolution was passed agreeing to abide by the court's orders. The adoption of the resolution became a point of substantial internal debate and controversy within the tribe. After a hearing on May 2, 1987, Tribal Chairman Doran Morris Sr. was jailed again for advising Judge McManus in open court to "go to hell." Later that month, when the judge entered his "Final Judgment and Decree" in the case, Morris publicly declared that the ruling "proves that he's a racist." "72

Ultimately, the courts held that the Omahas had failed to meet their burden of proving title to the remaining 700 acres in dispute, and awarded the land to the state of Iowa. Approximately 300 additional acres were awarded to various other non-Indian claimants for parcels that had previously been acquired by "fee patents." Thus, when the "Blackbird Bend I" litigation finally ground to a halt sixteen years after it commenced, the Omahas had been awarded title to approximately 1,900 acres out of the 2,900 acres within the Barrett Survey. In addition, the erstwhile "owners" of the land were awarded a

578 F. Supp. 1191 (W.D. Iowa 1984), in which Judge Bogue ruled in favor of the state of Iowa as to the 700 acres in dispute, and returned the case to Judge McManus for further handling on the issue of "improvements"; Omaha Indian Tribe v. Jackson, 854 F.2d 1089 (8th Cir. 1988), cert. denied 490 U.S. 1090 (1989), in which the Eighth Circuit affirmed the award of the 700 acres to the state of Iowa, and also affirmed an unpublished decision by Judge McManus awarding the Iowa landowners $\$ 1,921,177.85$ for the value of the improvements made to the land previously awarded to the Omahas; and finally, United States v. Wilson, 926 F.2d 725 (8th Cir. 1991), in which the circuit court held that the government must pay simple rather than compound prejudgment interest on the amount found owing to the Iowans.

72. Wynema Morris, interview with author, 5 February 1997; Doran Morris (who was chairman of the tribal council from 1981 to 1992, and remains a member of the council today), interview with author, 28 February 1997; Sioux City Journal, 3 and 6 June 1987. See also Omaha World-Herald, 11 February and 16 March 1987. 
judgment against the United States for almost \$2 million, plus prejudgment interest, for the value of the improvements made to the property before it was returned to the tribe.

Meanwhile, the tribe's claims to the acreage outside the Barrett Survey within the Blackbird Bend lobe, and the additional land in the Monona Bend and Omaha Mission Bend areas to the north, remained to be resolved. Those much larger claims, which now became known as "Blackbird Bend II," had been severed and placed in abeyance by Judge McManus in 1979. As the claims in Blackbird Bend I were resolved, Blackbird Bend II took center stage.

THE DOZENS OF IOWA FARMERS whose lands were at issue in Blackbird Bend II had been following the convoluted proceedings in Blackbird Bend I for years. As the threat to their lands was resurrected, tension within the community rose to new heights. Monona County Sheriff Albert Wood bluntly predicted bloodshed if the Omahas sought to "occupy" any of the contested land. "The boys have deeds to the land. They have paid taxes on it. They aren't about to give it up. If they get pushed too hard, I know what will happen. The river will run red." ${ }^{74}$

Although Wood's dire prediction of violence proved to be overstated, the Omahas' attempts to proceed with their remaining claims ultimately deteriorated into a long series of acrimonious confrontations and ad hominen attacks between the tribe's counsel, the attorneys for the Iowa landowners, and the federal judiciary. The evolution of the Omahas' "private" legal representation was, like all other aspects of the litigation, complex and convoluted. After he filed the Omahas' independent action in October 1975, the tribe's original counsel, John T. $\mathrm{O}^{\prime}$ Brien, was supplanted as counsel of record by his brother Donald E. O'Brien, a former county prosecutor. Their fees were paid by the Department of Interior, which later assigned one of its staff attorneys, William $\mathrm{H}$. Veeder, to assist in the case. Veeder and Donald O'Brien tried the case on behalf of the tribe.

73. Omaha World-Herald, 2 February 1986.

74. Ibid., 22 February 1980. 
O'Brien was later appointed to the federal bench himself, and representation of the tribe thereafter rested with Veeder alone. Veeder continued to represent the tribe as private counsel even after he left government service. In 1982 Secretary of the Interior James Watt cut off further funding of the Omahas' continuing appeals-yet another example, in the Omahas' view, of the governmental conspiracy against them. Nebraska Congressman Doug Bereuter agreed with the tribe, telling a news reporter at the time, "I'm upset by the fact that we've had political interference in the lawsuit. It seems to me that the secretary is not meeting his trust responsibility to the tribe..$^{\prime 75}$

As the Omahas continued to press their charges of fraud, conflict of interest, and collusion on the part of their opponents and the courts, procedural conflicts and animosity among the attorneys escalated to the point that the district court ultimately imposed the harshest possible sanction against the tribe. On May 29, 1990, Federal District Judge Warren Urbom entered an order in which he condemned the tribe's attorney, William H. Veeder, for his "systematic pattern of failure to comply with court rules and orders," and dismissed all of the Omahas' remaining claims. ${ }^{76}$ One year later, the Eighth Circuit Court upheld Urbom's ruling and assessed a penalty against the tribe of double the costs of the appeal for its continued prosecution of the "frivolous" claims of fraud and conspiracy." The judicial denunciation of William Veeder continued, as the court declared,

Mr. Veeder continues to exercise scurrilous disrespect for the judges involved in this case. He stands obsessed with the charges of fraud by Judges McManus and Urbom . . . notwithstanding this court's prior dismissal of such a claim. ... Mr. Veeder through

75. William H. Veeder, interview with author, 3 March 1997; Doran Morris, interview with author, 28 February 1997; Omaha World-Herald, 4 and 5 March 1982.

76. District Judge Warren Urbom, "Memorandum and Order," 29 May 1990, p. 10, Case No. C75-4067, Federal District Court for Northern District of Iowa, Western Division.

77. Omaha Indian Tribe v. Tract I-Blackbird Bend Area, 933 F.2d 1462 (8th Cir.) (per curiam), cert. denied sub nom. Omaha Indian Tribe v. Agricultural \& Indus. Inv. Co., 502 U.S. 942 (1991). 
his continued contumacious refusal to comply with the district court orders has done a great disservice to his client in important litigation. It is unfortunate in a case such as this that the client must live or die by the conduct of its counsel. ${ }^{78}$

When the Supreme Court denied the tribe's request for it to review the case later that year, the Omahas' claims were finally extinguished. Four more years would pass, however, before the courts resolved the last remaining issue in the case.

After the final dismissal of the Omahas' claims in Blackbird Bend II, two counterclaims against the tribe remained viable. Those counterclaims had been filed by the Iowans whose land the tribe had physically occupied since 1975, and they remained at issue because the tribe continued to occupy the property even after all of its remaining claims had been dismissed. In April 1993 the district court gave title to the land to the Iowans, and awarded them more than four hundred thousand dollars for the rental value of the land during the tribe's occupancy. In January 1995 the Eighth Circuit affirmed the district court's decision, and the twenty-nine-year-old legal struggle for Blackbird Bend finally came to an end. ${ }^{79}$

While the Iowans expressed joy and relief at the final disposition of the case, the Omahas vowed to fight on, suggesting that they might reoccupy the land or even take their claims to some other forum such as the United Nations or the World Court. ${ }^{80}$ No such action was ever taken, although the tribe did make a futile request to the Senate Judiciary Committee for an "oversight hearing" to investigate its grievances against the

\section{933 F.2d 1462, at 1471.}

79. See Rupp v. Omaha Indian Tribe, 45 F.3d 1241 (8th Cir. 1995). See also Sioux City Journal, 13 and 16 April 1993.

80 . Veeder described the court's ruling as a "great tragedy" and "another example of how the Indian tribes are being planned out of existence." Des Moines Register, 31 May 1991. One of the Iowa claimants, on the other hand, estimated that the group had spent more than two hundred thousand dollars to defend their claims, and described himself as "ecstatic" at the news of the final decision. Sioux City Journal, 8 November 1991. For other contemporary accounts of local reaction to the final decisions in the litigation, from both sides' perspectives, see Sioux City Journal, 31 May and 8 November 1991; and Des Moines Register, 31 May and 1 and 16 June 1991 (the latter includes photos of key personalities on both sides of the dispute). 
judges and government attorneys. ${ }^{81}$ Notwithstanding the Omahas' lingering discontent, their legal claims to the rest of the disputed land are permanently extinguished. The tribe was left with the 1,900 acres awarded to it in the Blackbird Bend I litigation, and the Iowans whose land had been threatened in Blackbird Bend II escaped on procedural grounds, without being required to defend against the Omahas' claims on their merits.

\section{A COMPLETE EPILOGUE to the Blackbird Bend story re-} mains to be written. It is too soon to draw any sweeping conclusions about the long-term impact of the litigation on the Omahas or their neighbors. Nevertheless, several summary observations can be made. First and foremost, the struggle for Blackbird Bend provides a compelling example of the vexing uncertainties and inherent contradictions that pervade the federal government's "trust" relationship with Native American tribes. If debacles like the government's forced "representation" of the Omahas at Blackbird Bend are to be avoided in the future, the precise nature and extent of those trust responsibilities must be reexamined and more clearly delineated. Mechanisms must be instituted to resolve adversarial conflicts between the "trustee" and the "beneficiary" before the rights of the ward are foreclosed as they were at Blackbird Bend.

81. In an unpublished letter dated 6 July 1990, Tribal Chairman Doran L. Morris asked Senator Joseph R. Biden, chair of the Senate Judiciary Committee, to investigate "the failure of the Federal Judiciary to fulfill its obligation to provide the Tribe a full and fair trial before a fair tribunal," and to remedy "the forced fraudulent representation [of the Tribe] by the attorneys in the Department of Justice." Cosigned and written by William Veeder, the 30-page letter recited a long litany of grievances against the government attorneys and the federal judges involved in the Blackbird Bend litigation. Although rambling in style, and obviously self-serving as to Veeder's culpability in the courts' dismissal of the tribe's claims, it is nevertheless a valuable reflection of the tribe's bitter outrage at the outcome in the Blackbird Bend cases. The committee never took any formal action in response to the tribe's request. In Veeder's words, "It was simply ignored." William H. Veeder, interview with author, 3 March 1997.

82. Much academic commentary has addressed various deficiencies in the trust relationship. See, for example, Daniel McNeill, "Trusts: Toward an Effective Indian Remedy for Breach of Trust," American Indian Law Review 8 (1980), 42957 , in which the author describes the trust as "a vaporous entity, whose shifting, uncertain contours have lent themselves to diverse and contradictory interpretations by different courts" (430). 
Another tangible legacy of the litigation may be found in the residue of resentment and frustration that lingers in and around Monona County today. Although almost all of the local landowners who were named in the litigation ultimately retained title to their land, the years of uncertainty and substantial legal expense they incurred have left their mark. Vincent Willey, the original chairman of the Monona County Landowners Association, provides a useful description of the local sentiment.

I've got empathy for many of the tribe's people, but things definitely got kind of hot there for a while. The lawsuits tied up everyone's land, held up estates, and generally created tremendous chaos. The people who stayed in the case to the end wound up spending between $\$ 150$ and $\$ 160$ per acre to defend their title to land that they held patents on for decades. There definitely is still some resentment.

One of the great ironies of the Blackbird Bend story is that the Omahas share their opponents' sense of lingering frustration. Wynema Morris, a member of the tribal council during much of the litigation, acknowledges a lasting "bitter resentment" at the way the courts ultimately derailed the tribe's claim for the vast majority of the land they still feel is theirs.

My mother still looks to that land and has a real visceral feel that it is our land. She gets very emotional whenever we get near Blackbird Bend. We know it is our land - the land of our ancestors. We still want it back. After all, our ancestors are the dust beneath our feet. $^{84}$

The Blackbird Bend litigation also contributed to a continuing pattern of dissension and factionalism within the tribe itself, as tribal members debated, sometimes quite vehemently, decisions that were made throughout the long process. ${ }^{85}$

83. Vincent Willey, interview with author, 21 February 1997. Other area residents interviewed for this article expressed similar or even stronger sentiments, but all asked not to be identified for publication.

84. Wynema Morris, interview with author, 5 February 1997.

85. One of the internal tribal debates centered on the question of payment of William Veeder's bills for legal services. One faction of the tribe felt that Veeder had "fought the good fight" against overwhelming odds and ought to be paid. Others argued that his actions had cost the tribe its claim for the vast majority 


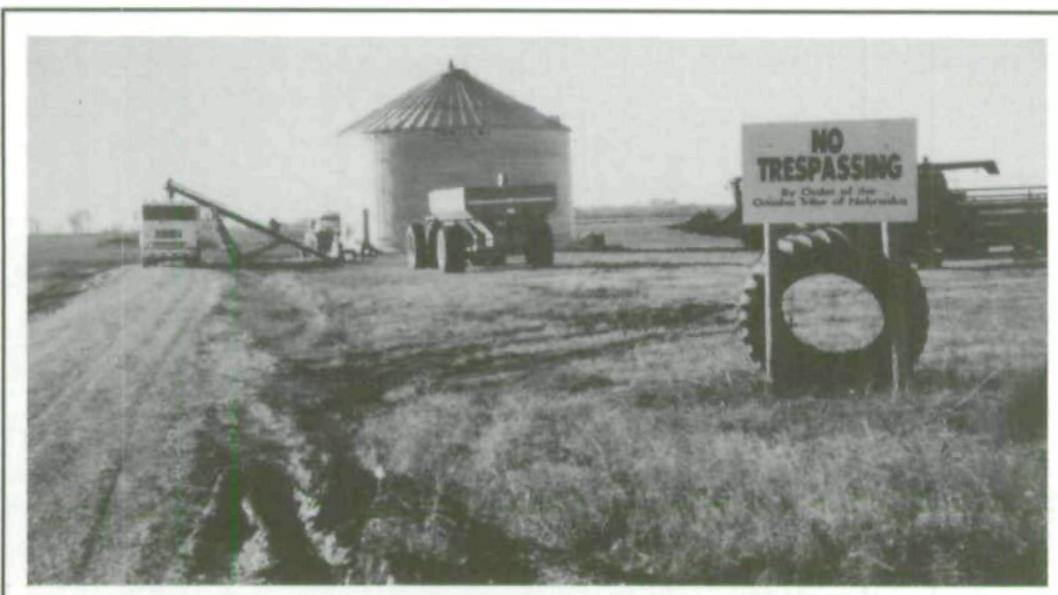

As Omaha farming operations proceed at Blackbird Bend, a sign in the foreground warns, "No Trespassing By Order of the Omaha Tribe of Nebraska." Photo, taken in October 1995, courtesy of the author.

On a more positive note, the struggle for Blackbird Bend represents one of the many steps taken by the Omaha tribe in the past few decades to "resurrect itself" as a vibrant and economically viable political and cultural entity. The courts' dismissal of most of the Omahas' claims as a punitive measure against the tribe's attorney casts an unsettling cloud on that determined effort. Nevertheless, the Omahas take a measure of satisfaction in knowing that a portion of the land they recovered in Iowa is now the site of the tribe's successful gaming operation, Casino Omaha. That enterprise, combined with the farming operations on the remainder of the land, has contributed significantly to the tribal revenue base over the past several years. They provide the most tangible legacy of the Omahas' "imperfect victory" at Blackbird Bend.

of the land at issue, and resisted payment. Ultimately, Veeder sued the tribe for payment, and he finally was paid $\$ 175,000$ in 1993 . In conversations with the author, tribal member Wynema Morris indicated that the positive view of Veeder's role is the "majority view" within the tribe. Wynema Morris, interview with author, 5 February 1997. Council member and former chairman Doran Morris agreed, stating, "There should be no animosity toward Bill Veeder at all. The land we regained, and the benefit we receive from it, are a result of his work." Doran Morris, interview with author, 28 February 1997. 
Copyright of Annals of Iowa is the property of State of Iowa, by \& through the State Historical Society of Iowa and its content may not be copied or emailed to multiple sites or posted to a listserv without the copyright holder's express written permission. However, users may print, download, or email articles for individual use. 